\title{
Article
}

\section{Novel Hybrid Compounds Containing Benzofuroxan and Aminothiazole Scaffolds: Synthesis and Evaluation of Their Anticancer Activity}

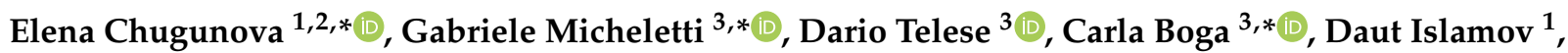 \\ Konstantin Usachev ${ }^{4}{ }^{\oplus}$, Alexander Burilov ${ }^{1,2}$, Alena Tulesinova ${ }^{5}$, Alexandra Voloshina ${ }^{1}$, Anna Lyubina ${ }^{1}$, \\ Syumbelya Amerhanova ${ }^{1}$, Tatiana Gerasimova ${ }^{1} \mathbb{D}$, Aisylu Gilfanova ${ }^{1}$ and Victor Syakaev ${ }^{1}$
}

Citation: Chugunova, E.; Micheletti, G.; Telese, D.; Boga, C.; Islamov, D.; Usachev, K.; Burilov, A.; Tulesinova, A.; Voloshina, A.; Lyubina, A.; et al. Novel Hybrid Compounds

Containing Benzofuroxan and Aminothiazole Scaffolds: Synthesis and Evaluation of Their Anticancer Activity. Int. J. Mol. Sci. 2021, 22, 7497. https://doi.org/10.3390/ijms22147497

Academic Editor: Antonio

Palumbo Piccionello

Received: 22 June 2021

Accepted: 8 July 2021

Published: 13 July 2021

Publisher's Note: MDPI stays neutra with regard to jurisdictional claims in published maps and institutional affiliations.

Copyright: (c) 2021 by the authors. Licensee MDPI, Basel, Switzerland This article is an open access article distributed under the terms and conditions of the Creative Commons Attribution (CC BY) license (https:// creativecommons.org/licenses/by/ $4.0 /)$
1 FRC Kazan Scientific Center, Arbuzov Institute of Organic and Physical Chemistry, Russian Academy of Sciences, 420088 Kazan, Russia; daut1989@mail.ru (D.I.); burilov_2004@mail.ru (A.B.); microbi@iopc.ru (A.V.); aplyubina@gmail.com (A.L.); syumbelya07@mail.ru (S.A.); tatyanagr@gmail.com (T.G.); aisylurafikovna@mail.ru (A.G.); vsyakaev@iopc.ru (V.S.)

2 Laboratory of Plant Infectious Diseases, FRC Kazan Scientific Center of Russian Academy of Sciences, 420111 Kazan, Russia

3 Department of Industrial Chemistry 'Toso Montanari', Alma Mater Studiorum-Universita di Bologna Viale Del Risorgimento, 40136 Bologna, Italy; dario.telese2@unibo.it

4 Kazan Institute of Biochemistry and Biophysics, FRC Kazan Scientific Center of Russian Academy of Sciences, 420111 Kazan, Russia; k.usachev@mail.ru

5 Institute of Chemical Engineering and Technology, Kazan National Research Technological University, 420015 Kazan, Russia; tulessinova.a@yandex.ru

* Correspondence: chugunova.e.a@gmail.com (E.C.); gabriele.micheletti3@unibo.it (G.M.); carla.boga@unibo.it (C.B.); Tel.: +7-843-272-7324 (E.C.); +39-051-209-3616 (G.M. \& C.B.)

Abstract: A series of novel hybrid compounds containing benzofuroxan and 2-aminothiazole moieties are synthesized via aromatic nucleophilic substitution reaction. Possible reaction pathways have been considered quantum-chemically, which allowed us to suggest the most probable products. The quantum chemical results have been proved by X-ray data on one compound belonging to the synthesized series. It was shown that the introduction of substituents to both the thiazole and amine moieties of the compounds under study strongly influences their UV/Vis spectra. Initial substances and obtained hybrid compounds have been tested in vitro as anticancer agents. Target compounds showed selectivity towards M-HeLa tumor cell lines and were found to be more active than starting benzofuroxan and aminothiazoles. Furthermore, they are considerably less toxic to normal liver cells compared to Tamoxifen. The mechanism of action of the studied compounds can be associated with the induction of apoptosis, which proceeds along the mitochondrial pathway. Thus, new hybrids of benzofuroxan are promising candidates for further development as anticancer agents.

Keywords: benzofuroxan; aminothiazole; anticancer activity; apoptosis; quantum chemicalcal culations

\section{Introduction}

Currently, oncological diseases are one of the most serious problems facing humanity, requiring the development of new drugs and methods of treatment. Cases of improving methods of therapy for oncological diseases, leading to a dramatic improvement in treatment results, are extremely rare, and most of the drugs used to treat cancer are toxic to the body as a whole [1].

There are several different classes of anticancer drugs based on their mechanisms of action: alkylating agents, antimetabolites, mitotic inhibitors, antineoplastic antibiotics, hormonal agents, and miscellaneous [2,3]. All anticancer drugs are not strictly specific; they act not only on tumor cells but also on normal cells, primarily on tissues with rapid proliferation (bone marrow, gastrointestinal mucosa) [4]. This determines the presence of toxic effects, which are often very serious, in almost all anticancer drugs. 
The end result of the action of all antitumor drugs is the inhibition of cell proliferation and the death of tumor cells (tumor regression) [5]. This effect is achieved by acting on various targets in the cell: DNA; RNA; enzymes necessary for normal DNA replication and repair; pathways for the intracellular transduction of mitogenic signals; the mitotic apparatus of the cell. As a result of these influences, apoptosis develops-programmed cell death. At the same time, the specific mechanisms for achieving these effects for different drugs within the same group may differ significantly, which is determined by the peculiarities of the chemical structure and metabolism of these compounds. For a number of drugs of different groups, the effect on several targets is characteristic.

Among anticancer drugs of the new generation, promising drugs are those that can selectively induce the death of cancer cells with minimal toxic effects in relation to healthy cells of the body [6]. Such selectivity can be based on the selective induction of death processes in cancer cells: apoptosis, autophagy, or necroptosis [7]. The search for such compounds is the key goal of our research.

2-Aminothiazoles, cyclic thiourea derivatives, are of great importance for pharmaceutical production, biochemistry, engineering, clinical and experimental medicine. 2Aminothiazole derivatives are used as disperse dyes in cotton industries [8], and mercaptothiazoles are vulcanization accelerators in the rubber industry [9]. These compounds showed high anti-inflammatory, analgesic, antioxidant [10], antiviral [11], antimycobacterial [12], antiplasmodial [13], anticancer [14], neuroprotective and anti-inflammatory properties [15] and other types of activity.

Derivatives of 2-aminothiazole, such as Norsulfazolum, Phthalylsulfathiazole, Khlotazol, Nitazol, Abafungin, Cefdinir, Meloxicam are widely used in medicine and veterinary medicine as a nonsteroidal anti-inflammatory and antimicrobial drugs (Figure 1).<smiles>CC(=O)Nc1ncc([N+](=O)[O-])s1</smiles>

Nitazol<smiles>OC(Nc1nccs1)C(Cl)(Cl)Cl</smiles>

Khlotazol<smiles>Nc1ccc(S(=O)(=O)Nc2nccs2)cc1</smiles>

Norsulfazolum<smiles>O=C(O)c1ccccc1C(=O)Nc1ccc(S(=O)(=O)Nc2nccs2)cc1</smiles><smiles>Cc1cc(C)cc(Oc2ccccc2-c2csc(NC3=NCCCN3)n2)c1</smiles>

Abafungin<smiles>C=CC1=C(C(=O)O)N2C(=O)C(NC(=O)C(=NO)c3csc(N)n3)C2SC1</smiles>

Cefdinir<smiles>Cc1cnc(NC(=O)C2=C(O)c3ccccc3S(=O)(=O)N2C)s1</smiles>

Meloxicam

Figure 1. Derivatives of 2-aminothiazole used in medicine and veterinary medicine.

In addition, the 2-aminothiazole molecule has a large number of reaction centers (endocyclic nitrogen atom, exocyclic $\mathrm{NH}_{2}$ and the carbon atom in Position 5, Figure 2), which prompts additional interest of research chemists in this compound.<smiles></smiles>

Figure 2. Three possible ways of the reaction between 2-aminothiazole and electrophiles. 
Our research group has been conducting research on the reactions of superelectrophilic benzofuroxans with various nucleophiles for a long time. Research was designed integrally, with direction dedicated to the synthesis of hybrid compounds [16-18]. It has been shown that the introduction of benzofuroxan fragments into the molecules of various pharmacophores leads to an increase in the biological activity or a decrease in the toxicity of the obtained products. Earlier, we made some studies on the interaction of benzofuroxans with aminothiazole derivatives [19-21]. Moreover, the study of such reactions is of interest to other research groups [22,23]. In the present study, we not only carried out a comprehensive study of the reactions of superelectrophilic 7-chloro-4,6-dinitrobenzofuroxan with 2-aminothiazole derivatives using NMR spectroscopy, X-ray diffraction analysis, UVspectroscopy and quantum chemical calculations, but also studied the anticancer activity of the compounds obtained.

\section{Results and Discussion}

\subsection{Chemistry}

\subsubsection{Quantum Chemical Calculations}

To shed light on the peculiarities of the interaction of 7-chloro-4,6-dinitrobenzofuroxan 1 with aminothiazoles 2 , the quantum-chemical study of these reactions has been carried out. On the example of the simplest representative of benzofuroxan and aminothiazole hybrids with $\mathrm{R}=\mathrm{R}_{2}=\mathrm{R}_{3}=\mathrm{H}$ 3a, three possible ways have been considered for aromatic nucleophilic substitution reaction: Pathway 1 -attack of electrophile on the exocyclic $\mathrm{NH}_{2}$, Pathway 2-attack of an electrophile on the endocyclic nitrogen atom and Pathway 3-attack on the carbon atom in Position 5 (Scheme 1).

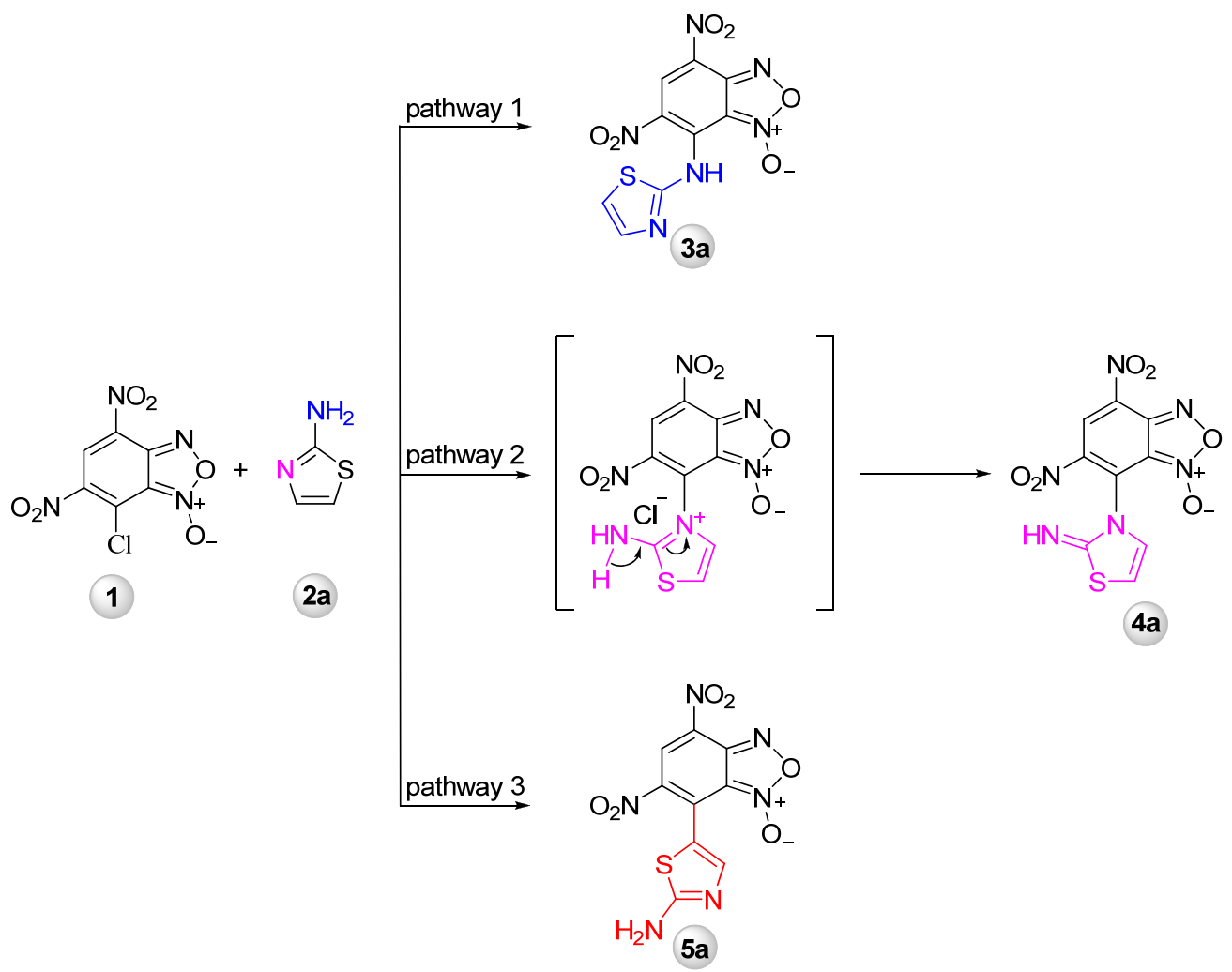

Scheme 1. Three possible ways for reaction of 7-chloro-4,6-dinitrobenzofuroxan 1 with 2-aminothiazole derivatives.

It is well known that 2-aminothiazole reacts with 2,4-dinitrofluorobenzene first with the endocyclic nitrogen atom [24]. Analysis of transition states for three considered ways shows the highest barrier for Pathway $3(18.3 \mathrm{kcal} / \mathrm{mol}$ compared to 12.8 and 13.2 for Pathways 2 and 1, respectively, Scheme 1). 
Among possible isomers, which can be formed through Pathways 1 and 2 (Scheme 2) both due to the N-1/N-3-oxide equilibrium and/or prototropic tautomerism in the molecule [25-28], the most stable one is 3aC; however, the energy difference between models with different locations of hydrogen (at amine/thiazole $\mathrm{N}: 3 \mathrm{aA} / 3 \mathrm{aC}$ and $3 \mathrm{aB} / \mathbf{3 a D}$ ) is less than $1 \mathrm{kcal} / \mathrm{mole}$, suggesting the possible coexistence of both structures (Table 1 ). The preferable location of the benzofuroxan oxygen moiety is at the N1 atom that is almost by $4 \mathrm{kcal} / \mathrm{mol}$ more advantageous compared to the tautomers with an oxygen atom located at N3. The products $\mathbf{4 a A}$ and $\mathbf{4 a B}$ that can be obtained by Pathway 2 are unfavorable (Table 1). Thus, one can assume that the reaction will more easily proceed by kinetically close Pathways 1 and 2; however, the first way is preferable, leading to, thermodynamically, much more stable products $(3 \mathrm{aC}$ and $3 \mathrm{aA})$.<smiles>C=COn1nc2c(Nc3nccs3)c(NO)cc([N+](=O)[O-])c2c1[N+](=O)[O-]</smiles><smiles>[R]N=c1sc([R3])c([R])n1-c1c([N+](=O)[O-])cc([N+](=O)[O-])c2c1no[n+]2[O-]</smiles>

Scheme 2. Possible tautomeric forms of benzofuroxans.

Table 1. Predicted relative energies $(\mathrm{kcal} / \mathrm{mol})$ of possible isomers of benzofuroxan and aminothiazole hybrids.

\begin{tabular}{ccccccc}
\hline Tautomer & 3aA & 3aB & 3aC & 3aD & 4aA & 4aB \\
\hline$\Delta \mathrm{E}$ & 0.9 & 4.6 & 0 & 3.9 & 14.6 & 16.3 \\
\hline
\end{tabular}

\subsubsection{Synthesis}

The synthesis of benzofuroxan and aminothiazole hybrids (Scheme 3) was realized via $\mathrm{S}_{\mathrm{N}} \mathrm{Ar}$ reaction between 7-chloro-4,6-dinitrobenzofuroxan $\mathbf{1}$ and 2-aminothiazole derivatives 2, in a 1:2 molar ratio, in chloroform (in $\mathrm{CH}_{2} \mathrm{Cl}_{2}$ for $2 \mathrm{c}$ ) at room temperature. The excess of 2-aminothiazole is used to neutralize the hydrogen chloride formed during the reaction. 


$$
\begin{aligned}
& \text { 2,3: } \mathrm{R}_{1}=\mathrm{R}_{2}=\mathrm{R}_{3}=\mathrm{H}(\mathrm{a}) ; \\
& \mathrm{R}_{1}=\mathrm{R}_{2}=\mathrm{H}, \mathrm{R}_{3}=\mathrm{CH}_{3}(\mathrm{~b}) ; \\
& \mathrm{R}_{1}=\mathrm{R}_{3}=\mathrm{H}, \mathrm{R}_{2}=\mathrm{COOC} 2 \mathrm{H}_{5}(\mathrm{c}) ; \\
& \mathrm{R}_{1}=\mathrm{Ph}, \mathrm{R}_{2}=\mathrm{R}_{3}=\mathrm{H}(\mathrm{d}) ; \\
& \mathrm{R}_{1}=\mathrm{Ph}, \mathrm{R}_{2}=\mathrm{H}, \mathrm{R}_{3}=\mathrm{CH},(\mathrm{e}) ; \\
& \mathrm{R}_{1}=p-\mathrm{OCH} \mathrm{H}_{3} \mathrm{Ph}, \mathrm{R}_{2}=\mathrm{R}_{3}=\mathrm{H}(\mathrm{f}) ; \\
& \mathrm{R}_{1}=m-\mathrm{ClPh}, \mathrm{R}_{2}=\mathrm{R}_{3}=\mathrm{H}(\mathrm{g})
\end{aligned}
$$

Scheme 3. Reaction of 7-chloro-4,6-dinitrobenzofuroxan 1 with 2-aminothiazoles.

The complete assignment of the signals in ${ }^{1} \mathrm{H},{ }^{13} \mathrm{C}$ and ${ }^{15} \mathrm{~N}$ NMR spectra was accomplished by using the 2D NMR techniques (COSY, HSQC, HMBC). As already mentioned above, benzofuroxans exist in the form of two tautomers. The presence of only one proton in the structure of the presented compounds significantly complicates the use of two-dimensional NMR experiments. In this case, the chemical shifts of carbons in these tautomeric forms do not differ significantly. Nevertheless, as we showed earlier [25], the difference between C3a and C7a allows us to quite unambiguously assign the observed tautomeric form of the benzofuroxan ring. Although, in the presented samples of compounds we observe only one form, based on a comparison with chemical shifts of previous compounds $[25,29]$, and the establishment of chemical shift C3a is unambiguously $147.3 \mathrm{ppm}$ from a cross-peak in the HMBC $(1 \mathrm{H}-13 \mathrm{C})$ spectrum, allowing us to assign them to the $\mathrm{A}$ form. The substituents' position is simply to consider the example of Compound 3d. In HMBC $\left({ }^{1} \mathrm{H}^{-15} \mathrm{~N}\right)$, spectra observed cross-peaks from ortho-protons of aryl ring (H78) to the N75 on 105 ppm, suggesting the pathway of reaction in Form 3 (see Structure 3 in Scheme 3 for numbering). For other compounds, the assignment can be made by analogy (The sufficiently large spin-spin coupling constants $J=1.2 \mathrm{~Hz}$ through four bonds observed between methyl protons and H75 in compounds $3 \mathbf{b}$ and $\mathbf{3 e}$ can also be noted. The complete assignment of the spectra (Figures S1-S14, Supplementary Materials) is given in the experimental part.

It should also be noted that, in the formation of Compound 3a, we observed, in addition to the main reaction product, the formation of a minor product also containing benzofuroxan and aminothiazole fragments; however, the value of the $\mathrm{C} 7 \mathrm{chemical}$ shift (162.7 ppm) did not allow us to relate this compound to any of the tautomers. Column chromatography purification allows for the individual isolation of the major product [20]. Comparison of the signals in ${ }^{1} \mathrm{H}$ and ${ }^{13} \mathrm{C}$ NMR spectra of mixtures of products with previously obtained results [30] allowed it to be identified as the salt 6 (Figure 3). In the case of the rest of the aminothiazole derivatives, we did not observe the formation of salts as by-products. 
<smiles>O=[N+]([O-])c1cc([N+](=O)[O-])c2c([N+](=O)[O-])onc2c1[N+](=O)[O-]</smiles>

Figure 3. The structure of the salt formed as a by-product.

According to X-ray data (Figure 4), Compound 3c crystallizes in the monoclinic space Group $P 2_{1}$. Benzofuroxan's bicyclic fragment is planar, and substituted nitro groups deviate from the plane of the bicycle. Hydrogen at the nitrogen atom is placed in geometrically calculated positions in the thiazole ring; however, the XRD data do not allow us to fully answer the question "To which nitrogen atom does hydrogen belong?".

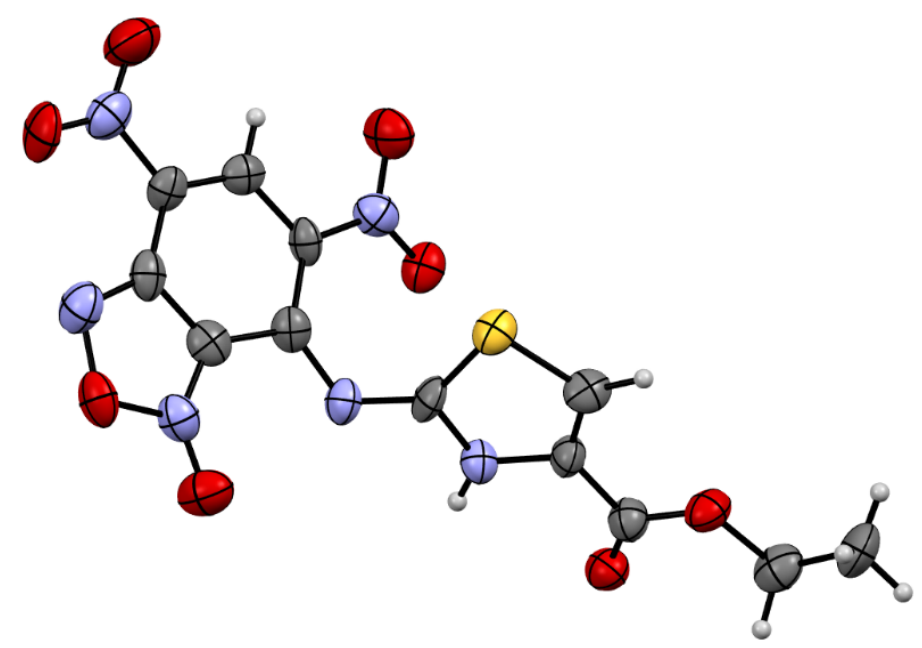

Figure 4. Molecular structure of Compound 3c. Yellow—sulfur, red—oxygen, blue—nitrogen, and grey-carbon.

This result confirms the structure of the product derived from Pathway 1 in Scheme 1.

\subsubsection{UV/Vis Spectral Analysis}

The nature and position of substituents in 3 significantly affect their color (Figure 5) and their electronic spectra (Figure 6a).

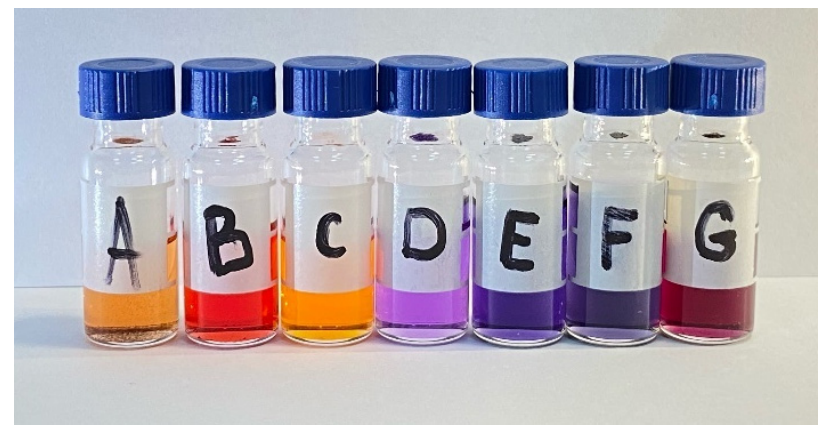

Figure 5. $\mathrm{CH}_{2} \mathrm{Cl}_{2}$ solutions of $\mathbf{3 a}-\mathbf{3 g}$. 


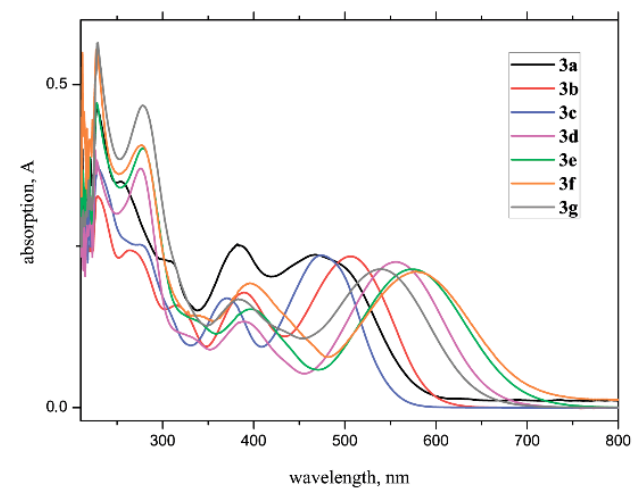

(a)

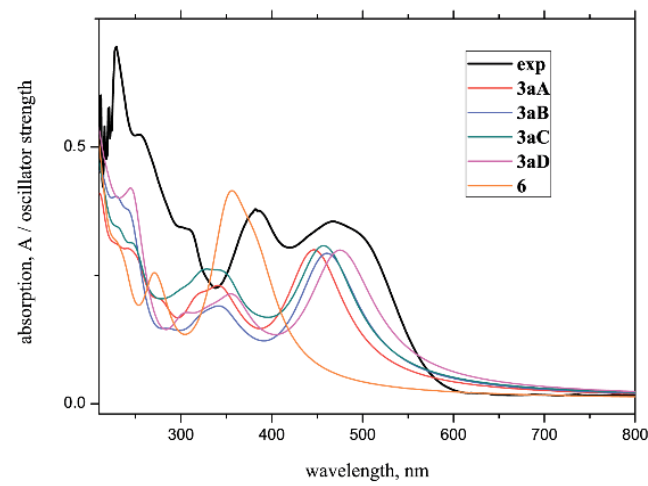

(b)

Figure 6. (a) Experimental UV/Vis spectra of 3a-3g, in $\mathrm{CH}_{2} \mathrm{Cl}_{2} ;(\mathbf{b})$ experimental UV/Vis spectrum of $3 \mathbf{a}$ and quantum-chemically simulated spectra of $3 \mathbf{a A}-3 \mathbf{a D}$ and 6 .

The UV/Vis spectra of 3a-3g demonstrate the lowest energy bands at 465-580 nm depending on $R_{1}-R_{3}$ with the shortest wavelength observed for $3 \mathbf{a}$ and $3 \mathbf{c}$ (Figure 6a). It should be mentioned that the lowest energy absorption in the 3a case consists of two bands. To shed light on the nature of these bands, several possible hypotheses have been considered quantum-chemically: the hydrolysis of 3a with the formation of 6 , and/or the 'formal migration' of the oxygen atom in the benzofuroxan moiety through $\mathrm{N}-1 / \mathrm{N}-3$-oxide equilibrium and the migration of hydrogen in the aminothiazole moiety by prototropic tautomerism (3aA-3aD, Scheme 2). The calculations predict a moderate blue shift of the low energy absorption band for Structures B and C compared to A (Figure 6b). Thus, both of them can explain two peaks at 450-500 nm. However, the analysis of relative energies of Isomers $\mathbf{3 a A}-\mathbf{3 a D}$ (Table 1 ) suggests that the spectrum of $\mathbf{3 a}$ is contributed by $\mathbf{3 a A}$ and $\mathbf{3 a C}$ forms. It should be mentioned that the absorption of hydrolyzed Molecule 6 is predicted to be significantly blue-shifted (by $\sim 90 \mathrm{~nm}$, Figure $6 \mathrm{~b}$ ) and most probably is associated with the observed experimental band at $383 \mathrm{~nm}$.

The introduction of substituents to both thiazole and amine moieties influences UV/Vis spectra of $\mathbf{3}$ (Figure 5, Table 2). Thus, in the UV/Vis spectrum of $\mathbf{3 b}$ with a methyl group in the thiazole ring, the longest wavelength is red shifted by $\sim 40 \mathrm{~nm}$ compared to $3 \mathbf{a}$. At the same time, ethoxycarbonyl group (3c) almost does not influence the corresponding absorption. Much stronger changes are observed for Compounds $\mathbf{3 d} \mathbf{- 3} \mathbf{g}$ with Ph group at amino-group. The replacement of a hydrogen atom by phenyl group leads to a significant red shift of the considered band by $90 \mathrm{~nm}$. Similar to $\mathbf{3 a - 3 b}$, the introduction of Me into a thiazole fragment results in a red shift of the band from 556 to 573. Additional tuning of absorption wavelength and color of Bf-aminothiazoles can be achieved by substituents in the Ph ring. The OMe group bathochromically shifts the band at 556 to $580 \mathrm{~nm}$; at the 
same time, the $\mathrm{Cl}$ atom leads to an inverse blue shift to $540 \mathrm{~nm}$. The computations correctly predict observed trends (Figure S15, Supplementary Materials; Table 2). According to computations, the longest wavelength absorptions are caused by transitions between the highest occupied and lowest unoccupied molecular orbitals (HOMO-LUMO), which are located at the whole molecules (Figure S16, Supplementary Materials). Nevertheless, for the compounds $3 \mathbf{a}-\mathbf{3} \mathbf{c}$, the contribution of benzofuroxan moieties both to HOMOs and LUMOs is higher compared to aminothiazole fragments. For the $\mathbf{3} \mathbf{d}-\mathbf{3 g}$ compounds, HOMOs are mostly localized on the Ph-aminothiazole moieties and LUMOs are mostly contributed by benzofuroxan fragments; thus, in these cases, corresponding transitions have a more pronounced charge transfer character, resulting in the higher wavelengths. It should be mentioned that both HOMO and LUMO of hydrolyzed Compound 6 are localized on the benzofuroxan.

Table 2. The experimental and calculated longest wavelength in the UV/Vis spectra of $\mathbf{3 a}-\mathbf{3 g}$.

\begin{tabular}{|c|c|c|c|c|c|c|}
\hline $3 a$ & $3 b$ & $3 c$ & $3 d$ & $3 e$ & $3 f$ & $3 g$ \\
\hline Experiment $467 / 494$ & 507 & 475 & 556 & 574 & 581 & 540 \\
\hline Computations 457 & 461 & 456 & 558 & 570 & 597 & 549 \\
\hline
\end{tabular}

\subsection{Biological Studies}

\subsubsection{Cytotoxic Assay}

Chemotherapy remains one of the most important methods of treating cancer, which, according to statistics, continues to rank second in the list of causes of death after cardiovascular diseases. For an effective fight against malignant tumors, a constant renewal of the drugs used is required. In this regard, the synthesized compounds were screened for cytotoxicity against a number of cancer and normal cell lines.

The cytotoxicity of all compounds against human normal and cancer cell lines was studied at concentrations of 1-100 $\mu \mathrm{M}$. The $\mathrm{IC}_{50}$ data for the tested compounds are presented in Table 3. The drugs tamoxifen and 5-fluorouracil widely used in medical practice were used as reference substances. It is seen that, in relation to the M-HeLa cancer line, the compounds $\mathbf{3 a}, \mathbf{3 d}, \mathbf{3} \mathbf{f}$ exhibit moderate cytotoxicity. Moreover, the Substances $\mathbf{3 a}, \mathbf{3 b}$, $3 \mathbf{e}$ and $\mathbf{3 f}$ turned out to be more active than their starting compounds. Compounds $3 \mathbf{a}$, $\mathbf{3 d}$ and $\mathbf{3 f}$ are more active in relation to the $\mathrm{M}-\mathrm{HeLa}$ cancer line than the reference drug 5 -fluorouracil and are slightly inferior to the reference substance tamoxifen. At the same time, the hybrid compounds $\mathbf{3 a}, \mathbf{3} \mathbf{d}$ and $\mathbf{3} \mathbf{f}$ are more selective in relation to normal cells than reference substances, that is, they are not toxic. In relation to the cancer cell lines HuTu 80, PANC-1 and the normal cell line Chang Liver, all tested compounds were found to be non-toxic.

\subsubsection{Induction of Apoptotic Effects by Test Compounds}

Currently, apoptosis is one of the main mechanisms of cytotoxic activity used in the development of new anticancer drugs [31]. Therefore, it is of considerable interest to study the apoptosis-inducing effect of the lead compound 3f. The study of apoptotic effects by flow cytometry makes it possible to establish whether the cytotoxic effect of the test compound is associated with the induction of apoptosis in M-HeLa cells. 
Table 3. Cytotoxic effects $\left(\mathrm{IC}_{50} \mu \mathrm{M}\right)$ of test compounds on the cancer and normal human cell lines *.

\begin{tabular}{|c|c|c|c|c|}
\hline \multirow[t]{2}{*}{ Test Compound } & \multicolumn{3}{|c|}{ Cancer Cell Line } & \multirow{2}{*}{$\begin{array}{l}\text { Normal Cell } \\
\text { Line } \\
\text { Chang Liver }\end{array}$} \\
\hline & M-HeLa & HuTu 80 & PANC-1 & \\
\hline 1 & $94.1 \pm 8.6$ & $>100$ & $>100$ & $>100$ \\
\hline $2 a$ & $91 \pm 8.3$ & $>100$ & $>100$ & $>100$ \\
\hline $3 a$ & $61.0 \pm 5.4$ & $>100$ & $>100$ & $>100$ \\
\hline $2 b$ & $92.0 \pm 7.9$ & $>100$ & $>100$ & $>100$ \\
\hline $3 b$ & $70.0 \pm 6.2$ & $>100$ & $>100$ & $>100$ \\
\hline $2 c$ & $63.3 \pm 5.7$ & $>100$ & $>100$ & $95.4 \pm 8.7$ \\
\hline $3 c$ & $95.8 \pm 8.4$ & $>100$ & $>100$ & $100 \pm 9.4$ \\
\hline $3 d$ & $61.0 \pm 5.6$ & $>100$ & $>100$ & $86.1 \pm 7.8$ \\
\hline $2 \mathrm{e}$ & $92 \pm 8.2$ & $>100$ & $>100$ & $>100$ \\
\hline $3 e$ & $79 \pm 6.3$ & $>100$ & $>100$ & $85.8 \pm 7.4$ \\
\hline $2 f$ & $93.8 \pm 8.4$ & $>100$ & $>100$ & $>100$ \\
\hline $3 f$ & $56.6 \pm 4.7$ & $>100$ & $>100$ & $>100$ \\
\hline Tamoxifen & $28.0 \pm 2.5$ & - & - & $46.2 \pm 3.5$ \\
\hline 5-Fluorouracil & $62.0 \pm 4.9$ & $65.2 \pm 5.5$ & $68.3 \pm 5.7$ & $72.4 \pm 6.5$ \\
\hline
\end{tabular}

* The experiments were repeated three times. The results are expressed as the mean \pm standard deviation (SD); - no cytotoxic effect.

As shown in Figure 7, after $24 \mathrm{~h}$ of incubation of the cells in the presence of Compound $3 \mathrm{f}$ at concentrations of 50 and $100 \mu \mathrm{M}$, apoptotic effects were observed. Moreover, they were most pronounced at the stage of early apoptosis at a concentration of $50 \mu \mathrm{M}$; Compound $3 \mathrm{f}$ induced early apoptosis in $10.73 \% \mathrm{M}-\mathrm{HeLa}$ cells. With an increase in the concentration of $3 \mathrm{f}$ to $100 \mu \mathrm{M}$, the number of apoptotic cells increased to $17.29 \%$. The results suggest that the cytotoxic effect of $3 \mathrm{f}$ in relation to M-HeLa cancer cells can be explained by an apoptotic pathway.
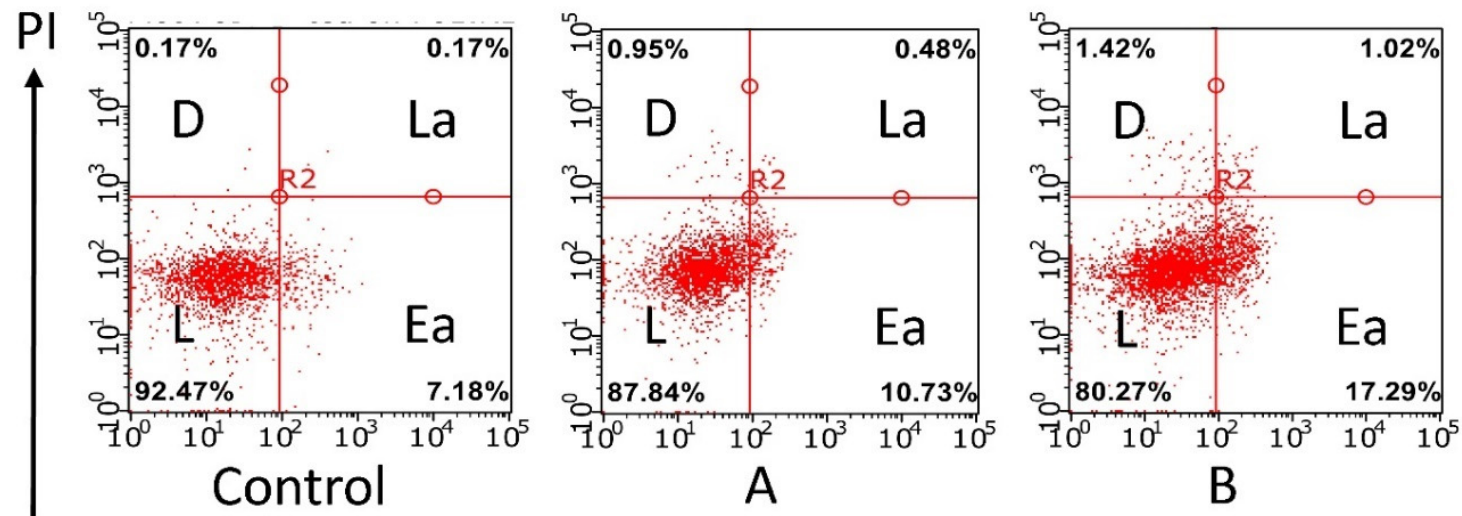

Annexin V

Figure 7. Apoptotic effects of $\mathbf{3 f}$ on M-HeLa cells. (A) M-HeLa cells were treated with the indicated compound $\mathbf{3 f}$ at a concentration of $50 \mu \mathrm{M}$. (B) M-HeLa cells were treated with the indicated compound $\mathbf{3 f}$ at a concentration of $100 \mu \mathrm{M}$. The values are presented as the mean $\pm \mathrm{SD}(n=3)$. L-living cells; D—dead cells; Ea-early apoptotic cells; La-late apoptotic cells.

\subsubsection{Effects on the Mitochondrial Membrane Potential $(\Delta \psi \mathrm{m})$}

Next, we studied the possible mechanism of the apoptosis-inducing effect of the compounds under study on cancer cells. There are two main mechanisms for the induction of apoptosis: an external pathway through death receptors and an internal pathway accompanied by a disruption of the mitochondrial membrane, which leads to a decrease in its potential and is a key indicator of the state of cells [32]. The ability of the studied compounds to cause a decrease in the mitochondrial membrane potential $(\Delta \psi \mathrm{m})$ in the cells of the M-HeLa culture was evaluated using the example of the lead compound $3 \mathbf{f}$. The 
studies were carried out by flow cytometry methods using the JC-10 reagent. In normal cells with a high mitochondrial membrane potential, the dye JC-10 forms aggregates (Jaggregate) near the mitochondrial membranes. When the membrane potential, due to the stimulation of apoptosis, falls, JC-10 is evenly distributed in the cell as a monomer (Jmonomer). JC-10 aggregates in normal cells have red fluorescence, while JC-10 monomers are green.

The ratio between red and green fluorescence can be used to judge the onset of apoptosis.

A reduction in $\Delta \psi \mathrm{m}$ was demonstrated using flow cytometry analysis (Figure 8). The intensity of the red fluorescence decreased with the increasing concentration of the test compound.
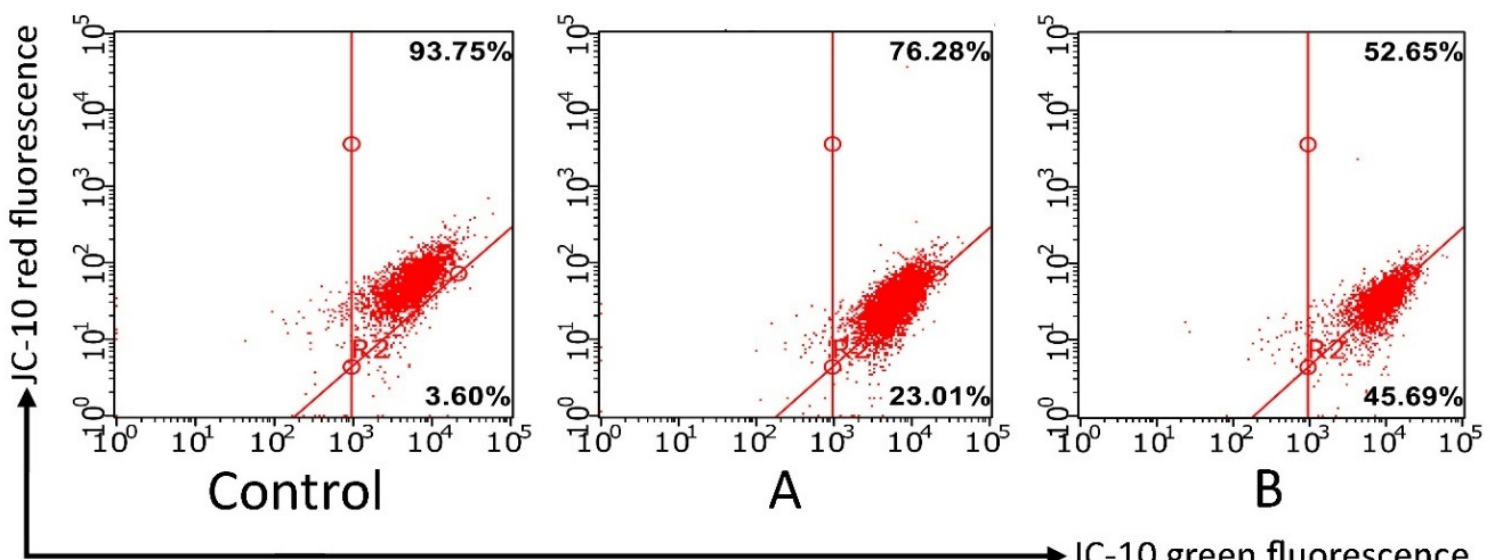

Figure 8. Flow cytometry analysis of M-HeLa cells treated with Compound 3f, along with the quantification of \% of cells with red and green aggregates. (A) M-HeLa cells were treated with the indicated compound $3 \mathbf{f}$ at a concentration of $50 \mu \mathrm{M}$. (B) M-HeLa cells were treated with the indicated compound $3 \mathrm{f}$ at a concentration of $100 \mu \mathrm{M}$. The values are presented as mean \pm SD.

The results obtained suggest that the mechanism of action of the studied compounds may be associated with the induction of apoptosis, which proceeds along the mitochondrial pathway.

\subsubsection{Cell Cycle Analysis}

Cell cycle analysis by quantification of DNA content is a reliable method to investigate which phase cell cycle has been arrested, wherein propidium iodide dye is used which binds in proportion to the amount of DNA present in the cell [33]. Results of cell cycle analysis using test Compound $3 \mathrm{f}$ against $\mathrm{M}-\mathrm{HeLa}$ cell lines by flow cytometry showed a transient G1 arrest of cells peaking at $24 \mathrm{~h}$. The results reveal that $3 \mathrm{f}$ caused an increase in \% of G1 arrest. Compound $3 f$ was on $81.4 \%$ and $83.8 \%$ at 50 and $100 \mu \mathrm{M}$, respectively, which is more than control cells (68.1\%) (Figure 9).

Regulation of the cell cycle is carried out by the activation of successively replacing cyclin-dependent kinases, which are a holoenzyme complex consisting of the catalytic subunit (Cdk) itself and the regulatory subunit, cyclin. Cyclin binding increases the kinase activity of $\mathrm{Cdk}$ and determines their localization and substrate specificity. The expression level of each of the cyclins and Cdk changes directionally at certain phases of the cell cycle. Thus, the transition from the G1 phase to the $S$ phase is associated with the formation of complexes of cyclin E with Cdk2. Based on the literature data [34], it can be assumed that the arrest of the cell cycle at the G1 stage may be due to a decrease in the expression of cyclin E and Cdk2 after the treatment of cells with the leader compound 3f. The expression of indicated proteins is further planned to be analyzed by Western blot analysis. 

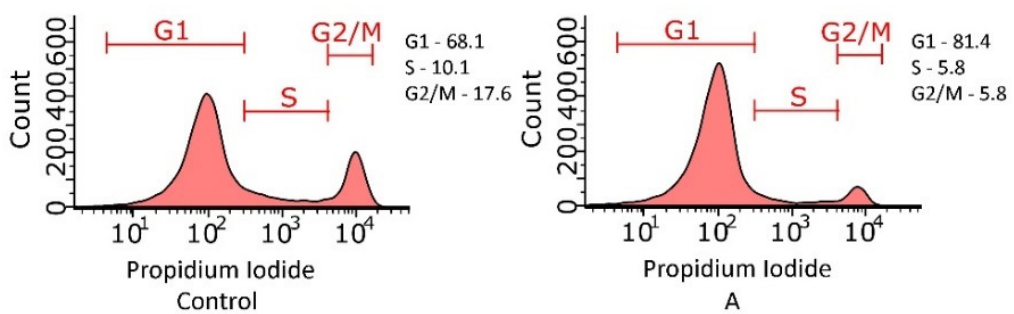

A

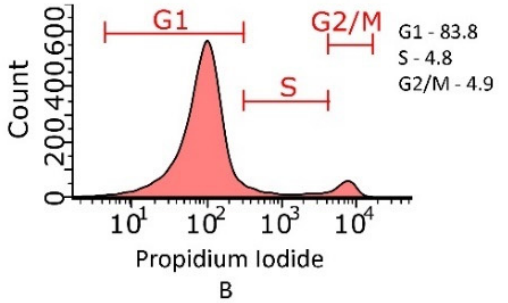

Figure 9. Effect of $3 \mathbf{f}$ on cell cycle progression of M-HeLa by flow cytometry. (A) M-HeLa cells were treated with the indicated compound $3 \mathbf{f}$ at a concentration of $50 \mu \mathrm{M}$. (B) M-HeLa cells were treated with the indicated compound $3 \mathbf{f}$ at a concentration of $100 \mu \mathrm{M}$.

Thus, the studies carried out have shown the perspective of introducing aminothiazole fragments into the benzofuroxan molecule. Compounds $\mathbf{3 a}, \mathbf{3 d}$ and $\mathbf{3 f}$ were more active in relation to the M-HeLa cancer line than the reference drug 5-fluorouracil and are slightly inferior to the reference substance tamoxifen. At the same time, Hybrid Compounds $\mathbf{3 a}, \mathbf{3 d}$ and $\mathbf{3 f}$ are more selective in relation to normal cells than reference substances, that is, they are not toxic. The highest activity was shown by Compound $3 \mathrm{f}$ containing methoxyphenyl as an additional substituent in the aminothiazole fragment. The importance of the methoxyphenyl fragment was also previously shown by us in previous studies of the antimicrobial activity of benzofuroxan derivatives [35]. The compound-leader $3 \mathbf{f}$ with the best $\mathrm{IC}_{50}$ in relation to the M-HeLa cancer cell line is promising for the production on their basis of low-toxic antitumor agents with selective cytotoxicity and tropism to tumor cells and not showing a cytotoxic effect in relation to normal cells.

\subsubsection{Absorption, Distribution, Metabolism, Excretion, and Toxicity Data (ADMET) Predictions}

ADMET properties of Starting Compound 1 and Hybrid Compounds 3a-g were investigated through SwissADME program (http:/ / swissadme.ch/, accessed on 7 July 2021). According to Lipinski's rule of five [36] and Ghose drug-like filter [37], all the designed compounds were in accordance with the rules by causing no more than one violation; thus, designed compounds seem to possess a good pharmacokinetic profile and might be approved for preclinical trials (Figures S17-S24, Supplementary Materials).

For all compounds, an inhibitory activity of Cytochrome P450 2C19 (CYP2C19) was found, whereas inhibitory activity of CYP2C9, another member of the CYP2C subfamily of the cytochrome P450, was found for Compounds $\mathbf{3 d}, \mathbf{3 e}$, and $\mathbf{3 f}$. Inhibitory activity of $\mathbf{3 c}$ and $3 \mathrm{f}$ towards CYP3A4 was also predicted. Always in the case of pharmacokinetics predictions, P-gp was recognized as a possible substrate for $\mathbf{3 a}, \mathbf{3 b}$, and $\mathbf{3 c}$ (see Supplementary Materials).

In addition, ADMET predictions for Compounds $\mathbf{1}$ and $\mathbf{3 a}-\mathbf{f}$ provided a list of their possible molecular targets (http://www.swisstargetprediction.ch/, accessed on 7 July 2021). It is worth noting that the most active compound, $\mathbf{3 f}$, has seven protein targets: proteases Matrix metalloproteinase 9 and Matrix metalloproteinase 2; family A G proteincoupled receptors Adenosine A1 and Adenosine A2a; enzyme PI3-kinase p110-gamma subunit; Dual specificity mitogen-activated protein kinase kinase 1 and MAP kinase p38 alpha while not active parent 7 -chloro-4,6-dinitrobenzofuroxan $\mathbf{1}$ has only one target, while for the least active compounds, $3 \mathbf{c}$ and $\mathbf{3 e}$, according to the predictions of the site, no possible targets were found.

\section{Conclusions}

A series of novel benzofuroxans derivatives were synthesized through a nucleophilic aromatic substitution reaction of 7-chloro-4,6-dinitrobenzofuroxan with 2-aminothiazoles. The results of the carried-out quantum-chemical computations show that the attack on the electrophilic C-5 carbon atom of the thiazole ring is kinetically disadvantageous; at the same time, reaction through the exocyclic $\mathrm{NH}_{2}$ leads to more thermodynamically 
preferable products compared to those derived from the involvement of the endocyclic nitrogen atom. The complete assignment of the signals in ${ }^{1} \mathrm{H},{ }^{13} \mathrm{C}$ and ${ }^{15} \mathrm{~N}$ NMR spectra by using the 2D NMR techniques (COSY, HSQC, HMBC) and X-ray data confirmed the results of the quantum-chemical study. The nature and position of substituents in compounds significantly affect their color and UV spectra. For the obtained compounds, the anticancer activity and possible mechanism of action on cancer cells were studied. In relation to the MHeLa cancer line, the substances $\mathbf{3 a}, \mathbf{3} \mathbf{b}, \mathbf{3 e}$ and $\mathbf{3} \mathbf{f}$ turned out to be more active than starting benzofuroxan, $\mathbf{1}$, and aminothiazoles, $\mathbf{2}$, while in relation to the normal cell line, ChangLiver-tested compounds were found to be non-toxic. Using flow cytometry methods, we showed that the mechanism of action of the studied compounds may be associated with the induction of apoptosis, which proceeds along the mitochondrial pathway. Thus, these compounds are promising candidates for further development of anticancer agents.

\section{Materials and Methods}

\subsection{Chemistry}

IR spectra were recorded in $\mathrm{KBr}$ or as emulsions in vaseline oil (sample concentration $0.25 \%$ ) on a Bruker Vector-22 spectrometer in the range $400-4000 \mathrm{~cm}^{-1}$; given are the most intense absorption bands. Electronic absorption (UV-Vis) spectra were recorded at room temperature on a Perkin-Elmer Lambda 35 spectrometer (PerkinElmer, Inc, Waltham, MA (Massachusetts), USA) using $10 \mathrm{~mm}$ quartz cells. Absorption spectra were registered with a scan speed of $480 \mathrm{~nm} / \mathrm{min}$, using a spectral width of $1 \mathrm{~nm}$. All samples were prepared as solutions in dichloromethane with the concentrations $\sim 10^{-5} \mathrm{~mol} \mathrm{~L}^{-1}$. Nuclear magnetic resonance (NMR) spectra were recorded on Brucker spectrometers AVANCEIII500 (Bruker BioSpin, Rheinstetten, Germany) $\left(500.1 \mathrm{MHz}\right.$ for ${ }^{1} \mathrm{H}, 125.8 \mathrm{MHz}$ for ${ }^{13} \mathrm{C}$ and $50.7 \mathrm{MHz}$ for ${ }^{15} \mathrm{~N}$ ) in acetone- $d_{6}$ at $303 \mathrm{~K}$. Chemical shifts were measured in $\delta(\mathrm{ppm})$ with reference to the solvent $\left(\delta=2.10 \mathrm{ppm}\right.$ and $30.5 \mathrm{ppm}$ for $\left(\mathrm{CD}_{3}\right)_{2} \mathrm{CO}$ for ${ }^{1} \mathrm{H}$ and ${ }^{13} \mathrm{C}$ NMR, respectively). The ${ }^{15} \mathrm{~N}$ NMR spectra are referenced to external urea and converted to the liquid anhydrous ammonia scale $\left(\left(\mathrm{NH}_{2}\right)_{2} \mathrm{C}(\mathrm{O}) \delta\left({ }^{15} \mathrm{~N}\right)=75 \mathrm{ppm}\right)$. The pulse programs of the COSY, HSQC and HMBC experiments were taken from the Bruker software library. Elemental analysis was performed on a CHNS-O Elemental Analyser EuroEA3028-HT-OM (EuroVector S.p.A., Milan, Italy) with an accuracy $\pm 0.4 \%$ for $\mathrm{C}, \mathrm{H}, \mathrm{Cl}, \mathrm{N}$ and S. The melting points were determined in glass capillaries on a Stuart SMP 10 instrument (Keison Products, Chelmsford, UK). The progress of reactions and the purity of products were monitored by TLC on Sorbfil UV-254 plates (Sorbpolimer, Krasnodar, Russia); the chromatograms were developed under UV light.

\subsubsection{X-ray Crystallography Data}

The data set for the single crystal $3 \mathrm{c}$ was collected on a Rigaku Synergy $S$ instrument (Rigaku Oxford diffraction, Tokyo, Japan) with a HyPix detector and a PhotonJet microfocus X-ray tube using $\mathrm{Cu} \mathrm{K} \alpha(1.54184 \AA)$ radiation at a low temperature. Images were indexed and integrated using the CrysAlisPro data reduction package. Data were corrected for systematic errors and absorption using the ABSPACK module: numerical absorption correction based on Gaussian integration over a multifaceted crystal model and empirical absorption correction based on spherical harmonics according to the point group symmetry using equivalent reflections. The GRAL module was used for the analysis of systematic absences and space group determination. The structure was solved by direct methods using SHELXT [38] and refined by the full-matrix least-squares on F2 using SHELXL [39]. Non-hydrogen atoms were refined anisotropically. The hydrogen atoms were inserted at the calculated positions and refined as riding atoms. The figures were generated using the Mercury v4.1 [40] program. Crystals were obtained by the slow evaporation method.

CCDC 2083328 (3c) contains the supplementary crystallographic data for this paper. These data can be obtained free of charge via www.ccdc.cam.ac.uk/conts/retrieving.html, accessed on 7 July 2021 (or from the Cambridge Crystallographic Data Centre, 12 Union Road, Cambridge CB2 1EZ, UK; fax: (+44) 1223-336-033; or deposit@ccdc.cam.uk). 


\subsubsection{Quantum-Chemical Computations}

All quantum-chemical computations were carried out with the use of Gaussian 16 suite of programs [41]. Calculations were performed with Becke's three-parameter hybrid exchange functional [42] and the gradient-corrected nonlocal correlation functional of Lee et al. [43] (B3LYP) in combination with standard 6-31G* basis set [44-46]. For all compounds (Schemes 4-11), geometry optimization of structures was performed without symmetry constraints. To ensure the calculated structures of reagents and products were indeed minima, vibrational analyses were performed using the same methods and were proved by all positive eigenvalues of the Hessian matrix. The transition states were confirmed by the presence of one negative eigenvalue in the Hessian matrix of the second derivatives. All calculations were performed for a singlet surface and the solutions found were tested for stability against perturbations imposed on the wave function using the Stable procedure.<smiles>O=[N+]([O-])c1cc([N+](=O)[O-])c2no[n+]([O-])c2c1Nc1nccs1</smiles>

Scheme 4. 4,6-dinitro-7-(thiazol-2-ylamino)benzo[c][1,2,5]oxadiazole 1-oxide (3a) (major product).<smiles></smiles>

Scheme 5. Thiazol-2-aminium 4,6-dinitro-7-oxidobenzo[c][1,2,5] oxadiazole 1-oxide (6) (minor product).<smiles>Cc1cnc(N(C)c2c([N+](=O)[O-])cc([N+](=O)[O-])c3nonc23)s1</smiles>

Scheme 6. 7-(5-methylthiazol-2-ylamino)-4,6-dinitrobenzo[c][1,2,5]oxadiazole 1-oxide (3b). 


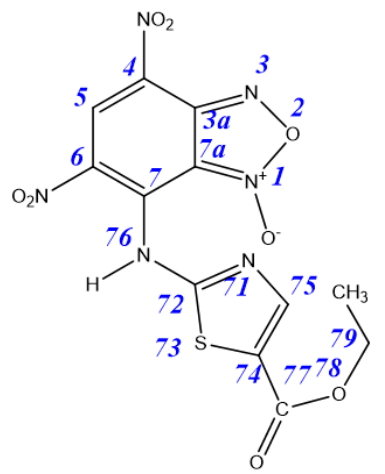

Scheme 7. 7-(5-(ethoxycarbonyl)thiazol-2-ylamino)-4,6-dinitrobenzo[c][1,2,5]oxadiazole 1-oxide (3c).

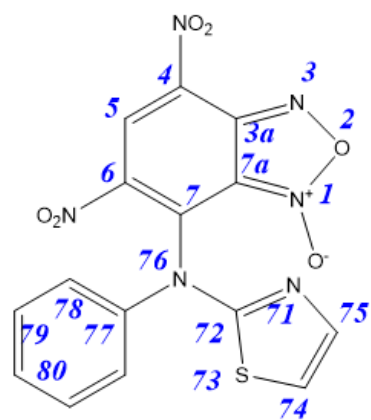

Scheme 8. 4,6-dinitro-7-(phenyl(thiazol-2-yl)amino)benzo[c][1,2,5]oxadiazole 1-oxide (3d).

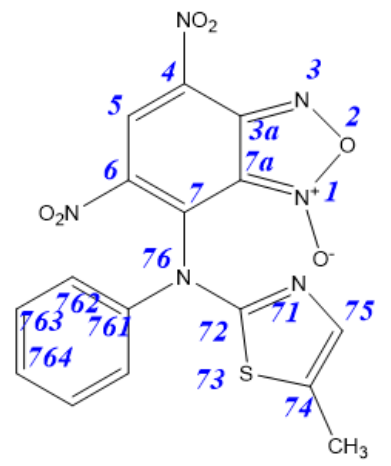

Scheme 9. 7-((5-methylthiazol-2-yl)(phenyl)amino)-4,6-dinitrobenzo[c][1,2,5]oxadiazole 1-oxide (3e).

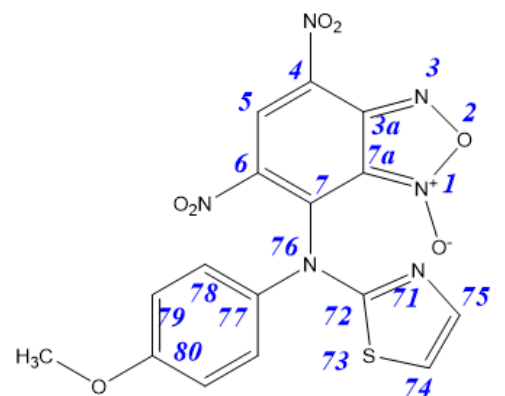

Scheme 10. 7-((4-methoxyphenyl)(thiazol-2-yl)amino)-4,6-dinitrobenzo[c][1,2,5]oxadiazole 1-oxide (3f). 


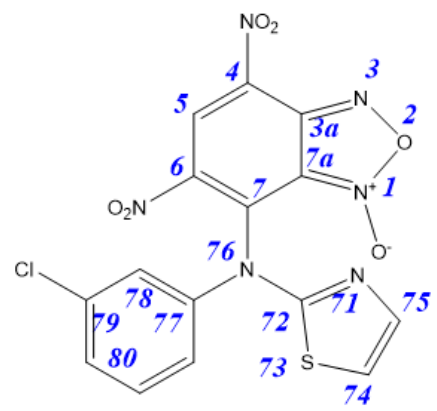

Scheme 11. 7-((3-chlorophenyl)(thiazol-2-yl)amino)-4,6-dinitrobenzo[c][1,2,5]oxadiazole 1-oxide (3g).

7-Chloro-4,6-dinitrobenzofuroxan 1 was synthesized according to the literature [47], 4,6-dinitro-7-(thiazol-2-ylamino)benzo[c][1,2,5]oxadiazole 1-oxide 3a was prepared according to [20], and 2-aminothiazoles were purchased by Sigma-Aldrich (Darmstadt, Germany).

Reaction between 7-chloro-4,6-dinitrobenzofuroxan $\mathbf{1}$ and aminothiazoles. A solution of Aminothiazole $2(0.0016 \mathrm{~mol})$ in $5 \mathrm{~mL}$ of $\mathrm{CHCl}_{3}$ or $\mathrm{CH} 2 \mathrm{Cl} 2$ was added to a solution of 7-chloro-4,6-dinitrobenzofuroxan $1(0.0008 \mathrm{~mol})$ in $5 \mathrm{~mL}$ of $\mathrm{CHCl}_{3}$ or $\mathrm{CH}_{2} \mathrm{Cl}_{2}$ at room temperature. The reaction was carried out at room temperature and under magnetic stirring, and the conversion was monitored through TLC analysis (eluent: toluene/ethyl acetate, 2:1). The mixture was stirred at room temperature overnight, the crude mixture was precipitated in hexane $(10 \mathrm{~mL})$, and the obtained solid was filtered off, washed with cold water $(100 \mathrm{~mL})$, and dried under vacuum $(0.06 \mathrm{~mm} \mathrm{Hg})$ at $40{ }^{\circ} \mathrm{C}$ to constant weight. The crude products were purified by column chromatography (eluent in each case was selected individually) to give the target compounds.

${ }^{1} \mathrm{H}$ NMR $\left(500 \mathrm{MHz}\right.$, Acetone- $\left.\mathrm{d}_{6}\right) \delta 7.30(\mathrm{~d}, J=4.4 \mathrm{~Hz}, 1 \mathrm{H}, \mathrm{H} 74), 7.65(\mathrm{~d}, J=4.4 \mathrm{~Hz}, 1 \mathrm{H}$, H75), 9.08 (s, 1H, H5). ${ }^{13} \mathrm{C}\left\{{ }^{1} \mathrm{H}\right\}$ NMR (126 MHz, Acetone- $\mathrm{d}_{6}$ ) $\delta 170.1$ (C72), $147.2(\mathrm{C} 3 \mathrm{a})$, 143.7 (C6), 133.2 (C5), 128.8 (C75), 127.1 (C7), 124.1 (C4), 112.2 (C74), 109.2 (C7a). ${ }^{15}$ N NMR $\left(51 \mathrm{MHz}\right.$, Acetone- $\left.\mathrm{d}_{6}\right) \delta \mathrm{N} 6,(\mathrm{~N} 4),(\mathrm{N} 71),(\mathrm{N} 76)$ no observed cross-peaks in spectra.

${ }^{1} \mathrm{H}$ NMR $\left(500 \mathrm{MHz}\right.$, Acetone- $\left.\mathrm{d}_{6}\right) \delta 7.16(\mathrm{~d}, J=4.4 \mathrm{~Hz}, 1 \mathrm{H}, \mathrm{H74}), 7.51(\mathrm{~d}, J=4.4 \mathrm{~Hz}, 1 \mathrm{H}$, H75), 9.24 (s, 1H, H5). ${ }^{13} \mathrm{C}\left\{{ }^{1} \mathrm{H}\right\}$ NMR (126 MHz, Acetone- $\left.\mathrm{d}_{6}\right) \delta 171.6$ (C72), 162.7 (C7), 148.6 (C3a), 135.1 (C5), 127.6 (C4), 126.8 (C75), 116.4 (C6), 112.7 (C7a), 109.1 (C74). ${ }^{15}$ N NMR (51 $\mathrm{MHz}$, Acetone- $\left.\mathrm{d}_{6}\right) \delta \mathrm{N6}$, (N4), (N71), (N76). no observed cross-peaks in spectra.

Eluent: ethyl acetate. Wine-colored powder, yield $62 \%$. M.p.: $210-212{ }^{\circ} \mathrm{C}$. IR $\left(v, \mathrm{~cm}^{-1}\right)$ : $1376\left(\mathrm{NO}_{2}\right.$ symm), $1548\left(\mathrm{NO}_{2}\right.$ asymm), 1620 (furoxan ring). ${ }^{1} \mathrm{H}$ NMR $(500 \mathrm{MHz}$, Acetone$\left.\mathrm{d}_{6}\right) \delta 2,44(\mathrm{~d}, J=1.2 \mathrm{~Hz}, 3 \mathrm{H}, \mathrm{CH} 3), 7.33(\mathrm{q}, J=1.2 \mathrm{~Hz}, 1 \mathrm{H}, \mathrm{H} 75), 9.04(\mathrm{~s}, 1 \mathrm{H}, \mathrm{H} 5) .{ }^{13} \mathrm{C}\left\{{ }^{1} \mathrm{H}\right\}$ NMR (126 MHz, Acetone-d 6 ) $\delta 171.1$ (C72), 148.5 (C3a), 144.4 (C6), 134.5 (C5), 127.7 (C7), 127.3 (C75), $127.3(\mathrm{C} 74), 123.4(\mathrm{C} 4), 113.9(\mathrm{C} 7 \mathrm{a}), 13.3\left(\mathrm{CH}_{3}\right) .{ }^{15} \mathrm{~N}$ NMR $\left(51 \mathrm{MHz}\right.$, Acetone- $\left.\mathrm{d}_{6}\right)$ $\delta 366.0$ (N6), 362,2 (N4), 189.5 (N71), n/o/ (N76). Anal. calcd (\%) for $\mathrm{C}_{10} \mathrm{H}_{6} \mathrm{~N}_{6} \mathrm{O}_{6} \mathrm{~S}: \mathrm{C} 35.51$; H 1.79; N 24.85; S 9.48. Found: C 35.59; H 1.82; N 24.79; S 9.42.

Purified by recrystallization from a mixture of chloroform/hexane (3:1). Purple powder, yield $93 \%$. M.p.: $188-189^{\circ} \mathrm{C}$. IR $\left(v, \mathrm{~cm}^{-1}\right): 1339\left(\mathrm{NO}_{2}\right.$ symm $), 1551\left(\mathrm{NO}_{2}\right.$ asymm), 1624 (furoxan ring), $1691(\mathrm{CO}), 1712(\mathrm{C}=\mathrm{O}), 3101(\mathrm{C} 5 \mathrm{H}) .{ }^{1} \mathrm{H}$ NMR $\left(500 \mathrm{MHz}\right.$, Acetone- $\left.\mathrm{d}_{6}\right) \delta$ $1.38(\mathrm{tr}, J=7.1 \mathrm{~Hz}, 3 \mathrm{H}, \mathrm{CH} 3), 4.38(\mathrm{q}, J=7.1 \mathrm{~Hz}, 2 \mathrm{H}, \mathrm{H79}), 8.10$ (s, 1H, H75), 9.09 (s, 1H, H5). ${ }^{13} \mathrm{C}\left\{{ }^{1} \mathrm{H}\right\}$ NMR (126 MHz, Acetone- $\left.\mathrm{d}_{6}\right) \delta 165.1$ (C72), 160.3 (C77), 148.0 (C3a), 140.0 (C6), 139.0 (C74), 133.0 (C5), 129.9 (C7), 127.5 (C4), 123.9 (C75), 114.0 (C7a), 63.0(C79), 15.1 (C80). ${ }^{15} \mathrm{~N}$ NMR (51 MHz, Acetone-d 6 ) $\delta 365.2$ N6, 361,2 (N4), 223.2 (N71), n/o/(N76). Anal. calcd (\%) for $\mathrm{C}_{12} \mathrm{H}_{8} \mathrm{~N}_{6} \mathrm{O}_{8} \mathrm{~S}$ : C 36.37; H 2.03; N 21.21; $\mathrm{S}$ 8.09. Found: $\mathrm{C} 36.36 ; \mathrm{H} 2.05 ; \mathrm{N}$ 21.21; S 8.13.

Crystal Data for $\mathrm{C}_{12} \mathrm{H}_{8} \mathrm{~N}_{6} \mathrm{O}_{8} \mathrm{~S}(M=396.30 \mathrm{~g} / \mathrm{mol})$ : monoclinic, space group $\mathrm{P}_{1}$ (no. 4), $a=11.6975(17) \AA, b=4.8735(8) \AA, c=14.135(3) \AA, \beta=104.348(15)^{\circ}, V=780.7(2) \AA^{3}, Z=2$, $T=99.9(7) \mathrm{K}, \mu(\mathrm{Cu} \mathrm{K} \alpha)=2.440 \mathrm{~mm}^{-1}$, Dcalc $=1.686 \mathrm{~g} / \mathrm{cm}^{3}, 4524$ reflections measured $\left(6.454^{\circ} \leq 2 \Theta \leq 152.63^{\circ}\right), 2377$ unique $\left(R_{\text {int }}=0.1287, R_{\text {sigma }}=0.1663\right)$ which were used in all calculations. The final $R_{1}$ was $0.1090(\mathrm{I}>2 \sigma(\mathrm{I}))$ and $w R_{2}$ was 0.2847 (all data). 
Eluent: chloroform. Violet powder, yield 57\%. M.p.: $112-113^{\circ} \mathrm{C}$. IR $\left(v, \mathrm{~cm}^{-1}\right): 1336$ ( $\mathrm{NO}_{2}$ symm), $1556\left(\mathrm{NO}_{2}\right.$ asymm), 1621 (furoxan ring). ${ }^{1} \mathrm{H} \mathrm{NMR}\left(500 \mathrm{MHz}\right.$, Acetone- $\left.\mathrm{d}_{6}\right)$ $\delta 7.35(\mathrm{~d}, J=3.6 \mathrm{~Hz}, 1 \mathrm{H}, \mathrm{H} 74), 7.41(\mathrm{~d}, J=3.6 \mathrm{~Hz}, 1 \mathrm{H}, \mathrm{H} 75), 7.49(\mathrm{~d}, J=7.6 \mathrm{~Hz}, 1 \mathrm{H}, \mathrm{H} 80)$, $7.54(\mathrm{tr}, J=7.6 \mathrm{~Hz}, 2 \mathrm{H}, \mathrm{H} 79), 7.63(\mathrm{~d}, J=7.6 \mathrm{~Hz}, 2 \mathrm{H}, \mathrm{H} 78), 8.96(\mathrm{~s}, 1 \mathrm{H}, \mathrm{H} 5) .{ }^{13} \mathrm{C}\left\{{ }^{1} \mathrm{H}\right\} \mathrm{NMR}$ (126 MHz, Acetone-d $\mathrm{d}_{6}$ ) $\delta 168.1$ (C72), 147.8 (C3a), 143.6 (C77), 141.5 (C75), 140.2 (C6), 135.4 (C7), 134.5 (C4), 131.7 (C5), 131.7 (C79), 130.3 (C80), 126.9 (C78), 117.1 (C74), 115.7 (C7a). ${ }^{15}$ N NMR (51 MHz, Acetone-d 6 ) $\delta 363.8$ (N6), 357.5 (N4), 285.1 (N71), 107.3 (N76). Anal. calcd (\%) for $\mathrm{C}_{15} \mathrm{H}_{8} \mathrm{~N}_{6} \mathrm{O}_{6} \mathrm{~S}: \mathrm{C} 45.00 ; \mathrm{H} 2.01 ; \mathrm{N} 20.99 ; \mathrm{S}$ 8.01. Found: C 45.05; H 1.98; N 20.95; S 8.06.

Eluent: chloroform. Blue powder, yield $77 \%$. M.p.: $169-170{ }^{\circ} \mathrm{C}$. IR $\left(\nu, \mathrm{cm}^{-1}\right): 1380$ $\left(\mathrm{NO}_{2}\right.$ symm), $1557\left(\mathrm{NO}_{2}\right.$ asymm), 1621 (furoxan ring). ${ }^{1} \mathrm{H}$ NMR $\left(500 \mathrm{MHz}\right.$, Acetone- $\left.\mathrm{d}_{6}\right) \delta$ $2.46(\mathrm{~d}, J=1.3 \mathrm{~Hz}, 3 \mathrm{H}, \mathrm{CH} 3), 7.08(\mathrm{q}, J=1.3 \mathrm{~Hz}, 1 \mathrm{H}, \mathrm{H75}), 7.46(\mathrm{tr}, J=8.2 \mathrm{~Hz}, 1 \mathrm{H}, \mathrm{H} 80), 7.52$ $(\operatorname{tr}, J=8.2 \mathrm{~Hz}, 2 \mathrm{H}, \mathrm{H} 79), 7.59(\mathrm{~d}, J=8.2 \mathrm{~Hz}, 2 \mathrm{H}, \mathrm{H} 78), 8.94(\mathrm{~s}, 1 \mathrm{H}, \mathrm{H} 5) .{ }^{13} \mathrm{C}\left\{{ }^{1} \mathrm{H}\right\} \mathrm{NMR}(126$ MHz, Acetone- $\mathrm{d}_{6}$ ) $\delta 164.8$ (C72), 146.8 (C3a), 142.5 (C77), 138.8 (C6), 137.8 (C75), 134.3 (C7), 133.0 (C4), 130.9 (C74), 130.6 (C5), 130.4 (C79), 129.1 (C80), 125.7 (C78), 114.7 (C7a), 11.6 (CH3). ${ }^{15} \mathrm{~N}$ NMR (51 MHz, Acetone-d 6 ) $8373.3(\mathrm{~N} 3), 366.1$ (N6), 357.1 (N4), 287.0 (N71), 108.5 (N76). Anal. calcd (\%) for $\mathrm{C}_{16} \mathrm{H}_{10} \mathrm{~N}_{6} \mathrm{O}_{6} \mathrm{~S}: \mathrm{C} 46.38 ; \mathrm{H} 2.43 ; \mathrm{N} 20.28 ; \mathrm{S}$ 7.74. Found: $\mathrm{C}$ $46.31 ; \mathrm{H} 2.49$; N 20.33; S 7.68 .

Eluent: chloroform. Blue powder, yield 51\%. M.p.: $176-178{ }^{\circ} \mathrm{C}$. IR $\left(v, \mathrm{~cm}^{-1}\right): 1378$ ( $\mathrm{NO}_{2}$ symm), $1558\left(\mathrm{NO}_{2}\right.$ asymm), 1621 (furoxan ring), $3101(\mathrm{C} 5 \mathrm{H}) .{ }^{1} \mathrm{H}$ NMR $(500 \mathrm{MHz}$, Acetone- $\left.\mathrm{d}_{6}\right) \delta 3.90(\mathrm{~s}, 3 \mathrm{H}, \mathrm{CH} 3), 7.07(\mathrm{~d}, J=9.0 \mathrm{~Hz}, 2 \mathrm{H}, \mathrm{H} 79), 7.32(\mathrm{~d}, J=3.5 \mathrm{~Hz}, 1 \mathrm{H}, \mathrm{H} 74)$, $7.39(\mathrm{~d}, J=3.5 \mathrm{~Hz}, 1 \mathrm{H}, \mathrm{H} 75), 7.56(\mathrm{~d}, J=9.0 \mathrm{~Hz}, 1 \mathrm{H}, \mathrm{H} 78), 8.94(\mathrm{~s}, 1 \mathrm{H}, \mathrm{H} 5) .{ }^{13} \mathrm{C}\left\{{ }^{1} \mathrm{H}\right\} \mathrm{NMR}$ (126 MHz, Acetone- $\mathrm{d}_{6}$ ) $\delta 168.8$ (C72), 161.6 (C80), 147.8 (C3a), 141.6 (C75), 139.6 (C6), 136.1 (C77), 135.3 (C7), 133.9 (C4), 131.6 (C5), 129.1 (C79), 117.0 (C74), 116.7 (C79), 115.7 (C7a), 56.7 (CH3). ${ }^{15} \mathrm{~N}$ NMR (51 MHz, Acetone-d 6 ) $\delta 364.2(\mathrm{~N} 6), 358.6$ (N4), 281.2 (N71), 106.4 (N76). Anal. calcd (\%) for $\mathrm{C}_{16} \mathrm{H}_{10} \mathrm{~N}_{6} \mathrm{O}_{7} \mathrm{~S}: \mathrm{C} 44.65 ; \mathrm{H} 2.34 ; \mathrm{N}$ 19.53; $\mathrm{S}$ 7.45. Found: $\mathrm{C} 44.62$; H 2.37; N 19.49; S 7.49.

Eluent: chloroform. Wine-colored powder, yield $63 \%$. M.p.: $74-75{ }^{\circ} \mathrm{C}$. IR $\left(v, \mathrm{~cm}^{-1}\right)$ : $1360\left(\mathrm{NO}_{2}\right.$ symm), $1556\left(\mathrm{NO}_{2}\right.$ asymm), 1621 (furoxan ring). ${ }^{1} \mathrm{H} \mathrm{NMR}(500 \mathrm{MHz}$, Acetone$\left.\mathrm{d}_{6}\right) \delta 7.350(\mathrm{~d}, J=3.6 \mathrm{~Hz}, 1 \mathrm{H}, \mathrm{H} 74), 7.409(\mathrm{~d}, J=3.6 \mathrm{~Hz}, 1 \mathrm{H}, \mathrm{H} 75), 7.485(\mathrm{~d}, J=7.6 \mathrm{~Hz}, 1 \mathrm{H}$, H80), $7.537(\operatorname{tr}, J=7.6 \mathrm{~Hz}, 2 \mathrm{H}, \mathrm{H} 79), 7.626(\mathrm{~d}, J=7.6 \mathrm{~Hz}, 1 \mathrm{H}, \mathrm{H} 78), 8.961(\mathrm{~s}, 1 \mathrm{H}, \mathrm{H} 5) .{ }^{13} \mathrm{C}\left\{{ }^{1} \mathrm{H}\right\}$ NMR (126 MHz Acetone-d $\mathrm{d}_{6}$ ) $\delta 167.4$ (C72), 147.7 (C3a), 144.6 (C79), 141.5 (C75), 140.1 (C6), 136.4 (C77), 134.9 (C7), 134.9 (C4), 132.8 (C81), 131.3 (C5), 130.0 (C80), 126.3 (C78), 125.3 (C82), 117.4 (C74), 115.7 (C7a). ${ }^{15} \mathrm{~N}$ NMR (51 MHz, Acetone-d 6 ) 8373.6 N3, 363.6 N6, 357.5 (N4), 285.4 (N71), 104.7 (N76). Anal. calcd (\%) for $\mathrm{C}_{15} \mathrm{H}_{7} \mathrm{ClN}_{6} \mathrm{O}_{6} \mathrm{~S}: \mathrm{C} 41.44 ; \mathrm{H} 1.62 ; \mathrm{Cl}$ 8.15; N 19.33; S 7.38. Found: C 41.52; H 1.55; Cl 8.23; N 19.37; S 7.44.

\subsection{Biological Studies}

\subsubsection{Cytotoxicity Assay}

Cytotoxic effects of the test compounds on human cancer and normal cells were estimated by means of the multifunctional Cytell Cell Imaging system (GE Health Care Life Science, Danderyd, Sweden) using the Cell Viability Bio App which precisely counts the number of cells and evaluates their viability from fluorescence intensity data [48]. DAPI and propidium iodide were purchased from Sigma. Two fluorescent dyes that selectively penetrate the cell membranes and fluoresce at different wavelengths were used in the experiments. The M-HeLa clone 11 human, epithelioid cervical carcinoma, the strain of HeLa, a clone of M-HeLa; PANC-1 is a human pancreatic cancer cell line; human duodenal cancer cell line (HuTu 80) from the Type Culture Collection of the Institute of Cytology (Russian Academy of Sciences, S-Petersburg, Russia) and Chang liver cell line (human liver cells) from N. F. Gamaleya Research Center of Epidemiology and Microbiology (Moscow, Russia) were used in the experiments. The cells were cultured in a standard Eagle's nutrient medium manufactured at the Chumakov Institute of Poliomyelitis and Virus Encephalitis (PanEco company, Moscow, Russia) and supplemented with 10\% fetal calf serum and $1 \%$ nonessential amino acids. The cells were plated into a 96-well plate (Nunc) 
at a concentration of $1 \times 10^{5}$ cells $/ \mathrm{mL}, 150 \mu \mathrm{L}$ of medium per well, and cultured in a $\mathrm{CO}_{2}$ incubator at $37^{\circ} \mathrm{C}$. Twenty-four hours after seeding the cells into wells, the compound under study was added at a preset dilution, $150 \mu \mathrm{L}$ to each well. The dilutions of the compounds were prepared immediately in nutrient media; $5 \%$ DMSO that does not induce the inhibition of cells at this concentration was added for better solubility. The experiments were repeated three times. Intact cells cultured in parallel with experimental cells were used as a control.

\subsubsection{Flow Cytometry Assay}

Cell Culture. M-HeLa cells at $1 \times 10^{6}$ cells/well in a final volume of $2 \mathrm{~mL}$ were seeded into 6-well plates. After $24 \mathrm{~h}$ of incubation, various concentrations of Compounds $\mathbf{2 f}$ and $3 \mathbf{f}$ were added to wells.

Cell Apoptosis Analysis. The cells were harvested at $2000 \mathrm{rpm}$ for $5 \mathrm{~min}$ and, then, washed twice with ice-cold PBS, followed by resuspension in binding buffer. Next, the samples were incubated with $5 \mu \mathrm{L}$ of annexin V-FITC and $5 \mu \mathrm{L}$ of propidium iodide for $15 \mathrm{~min}$ at room temperature in the dark. Finally, the cells were analyzed by flow cytometry (Guava easy Cyte, MERCK, Kenilworth Union County, NJ, USA). The experiments were repeated three times.

\subsubsection{Mitochondrial Membrane Potential}

The cells were harvested at $2000 \mathrm{rpm}$ for $5 \mathrm{~min}$ and, then, washed twice with ice-cold PBS, followed by resuspension in JC-10 $(10 \mu \mathrm{g} / \mathrm{mL})$ and incubation at $37^{\circ} \mathrm{C}$ for $10 \mathrm{~min}$. After the cells were rinsed three times and suspended in PBS, the JC-10 fluorescence was observed by flow cytometry.

\subsubsection{Cell Cycle Analysis}

The DNA content and cell-cycle distribution after genistein treatment were estimated by flow cytometry. Cell seeding, drug treatment and ethanol fixation were similar to cell proliferation assay. After washing with PBS, genistein and daidzein-treated and -fixed cells were suspended in $150 \mu \mathrm{L}$ of PBS, then $0.5 \mathrm{~mL}$ phosphate-citrate buffer $(0.05 \mathrm{M}, \mathrm{pH} 4.0)$ was added and the suspension was incubated at room temperature for $5 \mathrm{~min}$ to facilitate the extraction of low-molecular-weight DNA. Following centrifugation, the cells were resuspended in $150 \mu \mathrm{L}$ DNA staining solution $(20 \mu \mathrm{g} / \mathrm{mL}$ propidium iodide, $200 \mu \mathrm{g} / \mathrm{mL}$ DNase (RNase-free), and $0.1 \%$ Triton X-100) and incubated in the $\mathrm{CO}_{2}$ incubator $\left(37^{\circ} \mathrm{C}\right.$ for $30 \mathrm{~min}$ ). Cell cycle distribution was determined by fluorescence-activated cell sorting analysis of propidium iodide-stained ethanol-fixed cells using a Guava EasyCyte (Guava easy Cyte, MERCK, Kenilworth Union County, NJ, USA) [33].

\subsubsection{Statistical Analysis}

The cytometric results were analyzed by the Cytell Cell Imaging multifunctional system using the Cell Viability BioApp and Apoptosis BioApp application. The data in tables and graphs are given as the mean \pm standard error.

\subsubsection{ADMET Predictions}

The ADMET prediction server used was SwissADME (http://swissadme.ch/, accessed on 7 July 2021) from the Swiss Institute of Bioinformatics.

Supplementary Materials: The following are available online at https: / www.mdpi.com/article/ 10.3390/ijms22147497/s1: Figures S1-S14 copies of NMR spectra of all synthesized compounds, Figure S15-Experimental (black) vs. theoretical (red) UV/Vis spectra of 3a-3g, S16-Frontier orbitals of 3a-3g and 6, Figure S17-S24 ADMET predictions.

Author Contributions: E.C.-writing-original draft preparation, supervision (chemistry), C.B., A.B.-project administration and funding, A.T., G.M., D.T.-investigation (chemistry), A.V.supervision (in vitro anticancer studies), A.L., S.A.-investigation (in vitro anticancer studies), T.G.- 
software, investigation (quantum-chemical computations), A.G.-investigation (UV study), V.S.investigation (NMR study), D.I., K.U.-investigation (X-ray study). All authors have read and agreed to the published version of the manuscript.

Funding: Quantum-chemical computations and the study of in vitro anticancer activity were funded by the government assignment for the FRC Kazan Scientific Center of RAS. The synthesis was supported by the Ministry of Science and Higher Education of the Russian Federation (grant No. 07515-2019-1881).

Institutional Review Board Statement: Not applicable.

Informed Consent Statement: Not applicable.

Data Availability Statement: The data presented in this study are contained within the article or in Supplementary Materials, or are available on request from the corresponding author Elena Chugunova.

Acknowledgments: The authors are grateful to the Assigned Spectral-Analytical Center of FRC Kazan Scientific Center of RAS for technical assistance in research. C. Boga, G. Micheletti and D. Telese are grateful to Alma Mater Studiorum-Università di Bologna for funding this research.

Conflicts of Interest: The authors declare no conflict of interest.

\section{References}

1. Falzone, L.; Salomone, S.; Libra, M. Evolution of Cancer Pharmacological Treatments at the Turn of the Third Millennium. Front. Pharmacol. 2018, 9, 1300. [CrossRef]

2. Huang, C.-Y.; Ju, D.-T.; Chang, C.-F.; Muralidhar Reddy, P.; Velmurugan, B.K. A review on the effects of current chemotherapy drugs and natural agents in treating non-small cell lung cancer. BioMedicine 2017, 7, 23. [CrossRef] [PubMed]

3. Kalia, V.C.; Patel, S.K.S.; Cho, B.-K.; Wood, T.K.; Lee, J.-K. Emerging applications of bacteria as antitumor agents. Semin. Cancer Biol. 2021. [CrossRef]

4. Weber, G.F. DNA Damaging Drugs. Mol. Ther. Cancer 2014, 9-112. [CrossRef]

5. Dilshad, E.; Bibi, M.; Sheikh, N.A.; Tamrin, K.F.; Mansoor, Q.; Maqbool, Q.; Nawaz, M. Synthesis of Functional Silver Nanoparticles and Microparticles with Modifiers and Evaluation of Their Antimicrobial, Anticancer, and Antioxidant Activity. J. Funct. Biomater. 2020, 11, 76. [CrossRef]

6. $\quad$ Otari, S.V.; Kumar, M.; Anwar, M.Z.; Thorat, N.D.; Patel, S.K.S.; Lee, D.; Lee, J.H.; Lee, J.-K.; Kang, Y.C.; Zhang, L. Rapid synthesis and decoration of reduced graphene oxide with gold nanoparticles by thermostable peptides for memory device and photothermal applications. Sci. Rep. 2017, 7, 10980. [CrossRef]

7. Otari, S.V.; Pawar, S.H.; Patel, S.K.S.; Singh, R.K.; Kim, S.-Y.; Lee, J.H.; Zhang, L.; Lee, J.-K. Canna edulis Leaf Extract-Mediated Preparation of Stabilized Silver Nanoparticles: Characterization, Antimicrobial Activity, and Toxicity Studies. J. Microbiol. Biotechnol. 2017, 27, 731-738. [CrossRef]

8. Singh, K.; Singh, S.; Taylor, J.A. Monoazo disperse dyes-Part 1: Synthesis, spectroscopic studies and technical evaluation of monoazo disperse dyes derived from 2-aminothiazoles. Dye. Pigment. 2002, 54, 189-200. [CrossRef]

9. Trivette, C.D., Jr.; Morita, E.; Young, E.J. 2-Mercaptothiazole and Derivatives as Vulcanization Accelerators. Rubber Chem. Technol. 1962, 35, 1360-1429. [CrossRef]

10. Khan, E.; Khan, A.; Gul, Z.; Ullah, F.; Tahir, M.N.; Khalid, M.; Asif, H.M.; Asim, S.; Braga, A.A.C. Molecular salts of terephthalic acids with 2-aminopyridine and 2-aminothiazole derivatives as potential antioxidant agents; Base-Acid-Base type architectures. $J$. Mol. Struct. 2020, 1200, 127126. [CrossRef]

11. Venkatachalam, T.K.; Mao, C.; Uckun, F. Effect of stereochemistry on the anti-HIV activity of chiral thiourea compounds. Bioorg. Med. Chem. 2004, 12, 4275-4284. [CrossRef]

12. Chugunova, E.; Boga, C.; Sazykin, I.; Cino, S.; Micheletti, G.; Mazzanti, A.; Sazykina, M.; Burilov, A.; Khmelevtsova, L.; Kostina, N. Synthesis and antimicrobial activity of novel structural hybrids of benzofuroxan and benzothiazole derivatives. Eur. J. Med. Chem. 2015, 93, 349-359. [CrossRef]

13. Mjambili, F.; Njoroge, M.; Naran, K.; De Kock, C.; Smith, P.J.; Mizrahi, V.; Warner, D.; Chibale, K. Synthesis and biological evaluation of 2-aminothiazole derivatives as antimycobacterial and antiplasmodial agents. Bioorg. Med. Chem. Lett. 2014, 24, 560-564. [CrossRef]

14. Wan, Y.; Long, J.; Gao, H.; Tang, Z. 2-Aminothiazole: A privileged scaffold for the discovery of anti-cancer agents. Eur. J. Med. Chem. 2021, 210, 112953. [CrossRef] [PubMed]

15. Hussein, A.H.M.; Khames, A.A.; El-Adasy, A.-B.A.; Atalla, A.A.; Abdel-Rady, M.; Hassan, M.I.A.; Nemr, M.T.M.; Elshaier, Y.A.A.M. Design, synthesis and biological evaluation of new 2-aminothiazole scaffolds as phosphodiesterase type 5 regulators and COX-1/COX-2 inhibitors. RSC Adv. 2020, 10, 29723-29736. [CrossRef] 
16. Chugunova, E.A.; Akylbekov, N.I.; Voloshina, A.D.; Kulik, N.V.; Zobov, V.V.; Babaev, V.M.; Gavrilov, N.V.; Burilov, A.R. Synthesis and investigation of antimicrobial activity of compounds derived from benzo[c][1,2,5]oxadiazole-1-oxides and phenolates. Synth Commun. 2016, 46, 1560-1565. [CrossRef]

17. Serkov, I.V.; Chugunova, E.A.; Burilov, A.R.; Bachurin, S.O. Synthesis of amino acid derivatives of benzofuroxan. Dokl. Chem. 2013, 450, 149-151. [CrossRef]

18. Chugunova, E.A.; Akylbekov, N.I.; Appazov, N.O.; Makhrus, E.M.; Burilov, A.R. Synthesis of the first tertiary ammonium derivative of 6-chloro-5-nitrobenzofuroxan. Russ. J. Org. Chem. 2016, 52, 920-921. [CrossRef]

19. Boga, C.; Del Vecchio, E.; Forlani, L.; Goumont, R.; Terrier, F.; Tozzi, S. Evidence for the intermediacy of Wheland-Meisenheimer complexes in SEAr reactions of aminothiazoles with 4,6-dinitrobenzofuroxan. Chemistry 2007, 13, 9600-9607. [CrossRef] [PubMed]

20. Micheletti, G.; Telese, D.; Boga, C. 4,6-Dinitro-7-(thiazol-2-ylamino)benzo[c][1,2,5]oxadiazole 1-oxide. Molbank 2020, 2020, M1165. [CrossRef]

21. Forlani, L.; Boga, C.; Mazzanti, A.; Zanna, N. Trapping and Analysing Wheland-Meisenheimer $\sigma$ Complexes, Usually Labile and Escaping Intermediates. Eur. J. Org. Chem. 2012, 2012, 1123-1129. [CrossRef]

22. Alenzi, R.A.; El Guesmi, N.; Shaaban, M.R.; Asghar, B.H.; Farghaly, T.A. Assessing the nucleophilic character of 2-amino-4arylthiazoles through coupling with 4,6-dinitrobenzofuroxan: Experimental and theoretical approaches based on structurereactivity relationships. J. Saudi Chem. Soc. 2020, 24, 754-764. [CrossRef]

23. El Guesmi, N.; Hussein, E.M.; Asghar, B.H.; Obaid, R.J.; Jassas, R.S.; Alharbi, A.; Altass, H.M.; Althagafi, I.I.; Morad, M.; Moussa, Z.; et al. Nucleophilicity and solvent effects on the kinetics of 4-(pyren-1-yl)thiazol-2-amine interaction with 4,6dinitrobenzofuroxan. Arab. J. Chem. 2020, 13, 3702-3713. [CrossRef]

24. Forlani, L.; De Maria, P.; Foresti, E.; Pradella, G. Reactivity of 2-aminothiazole toward 2,4-dinitrofluorobenzene. Products and structures. J. Org. Chem. 1981, 46, 3178-3181. [CrossRef]

25. Chugunova, E.; Akylbekov, N.; Shakirova, L.; Dobrynin, A.; Syakaev, V.; Latypov, S.; Bukharov, S.; Burilov, A. Synthesis of hybrids of benzofuroxan and N-, S-containing sterically hindered phenols derivatives. Tautomerism. Tetrahedron 2016, 72, 6415-6420. [CrossRef]

26. Micheletti, G.; Iannuzzo, L.; Calvaresi, M.; Bordoni, S.; Telese, D.; Chugunova, E.; Boga, C. Intriguing enigma of nitrobenzofuroxan's "Sphinx": Boulton-Katritzky rearrangement or unusual evidence of theN-1/N-3-oxide rearrangement? RSC Adv. 2020, 10. [CrossRef]

27. Forlani, L.; De Maria, P. Tautomerism of aminothiazoles. pKBH+ Values of 2-aminothiazoles and of some model imines. J. Chem. Soc. Perkin Trans. 1982, 2, 535-537. [CrossRef]

28. Phukan, N.; Baruah, J.B. Imine-tautomers of aminothiazole derivatives: Intriguing aspects of chemical reactivities. CrystEngComm 2016, 18, 3877-3890. [CrossRef]

29. Chugunova, E.A.; Akylbekov, N.I.; Mahrous, E.M.; Voloshina, A.D.; Kulik, N.V.; Zobov, V.V.; Strelnik, A.G.; Gerasimova, T.P.; Dobrynin, A.B.; Burilov, A.R. Synthesis and study of antimicrobial activity of quaternary ammonium benzofuroxan salts. Monatshefte Fur Chemie Chem. Mon. 2018, 149, 119-126. [CrossRef]

30. Chugunova, E.; Akylbekov, N.; Bulatova, A.; Gavrilov, N.; Voloshina, A.; Kulik, N.; Zobov, V.; Dobrynin, A.; Syakaev, V.; Burilov, A. Synthesis and biological evaluation of novel structural hybrids of benzofuroxan derivatives and fluoroquinolones. Eur. J. Med. Chem. 2016, 116, 165-172. [CrossRef]

31. Elmore, S. Apoptosis: A review of programmed cell death. Toxicol. Pathol. 2007, 35, 495-516. [CrossRef]

32. Green, D.R.; Llambi, F. Cell Death Signaling. Cold Spring Harb. Perspect. Biol. 2015, 7, a006080. [CrossRef] [PubMed]

33. Garifullin, B.F.; Strobykina, I.Y.; Khabibulina, L.R.; Sapunova, A.S.; Voloshina, A.D.; Sharipova, R.R.; Khairutdinov, B.I.; Zuev, Y.F.; Kataev, V.E. Synthesis and cytotoxicity of the conjugates of diterpenoid isosteviol and N-acetyl-D-glucosamine. Nat. Prod. Res. 2019. [CrossRef]

34. Han, J.; Kurita, Y.; Isoda, H. Genistein-induced G2/M cell cycle arrest of human intestinal colon cancer Caco-2 cells is associated with Cyclin B1 and Chk2 down-regulation. Cytotechnology 2013, 65, 973-978. [CrossRef] [PubMed]

35. Chugunova, E.A.; Voloshina, A.D.; Mukhamatdinova, R.E.; Serkov, I.V.; Proshin, A.N.; Gibadullina, E.M.; Burilov, A.R.; Kulik, N.V.; Zobov, V.V.; Krivolapov, D.B.; et al. The Study of the Biological Activity of Amino-Substituted Benzofuroxans. Lett. Drug Des. Discov. 2014, 11, 502-512. [CrossRef]

36. Lipinski, C.A.; Lombardo, F.; Dominy, B.W.; Feeney, P.J. Experimental and Computational Approaches to Estimate Solubility and Permeability in Drug Discovery and Development Settings. Adv. Drug Deliv. Rev. 2001, 46, 3-26. [CrossRef]

37. Ghose, A.K.; Viswanadhan, V.N.; Wendoloski, J.J. A Knowledge-Based Approach in Designing Combinatorial or Medicinal Chemistry Libraries for Drug Discovery. 1. A Qualitative and Quantitative Characterization of Known Drug Databases. J. Comb. Chem. 1999, 1, 55-68. [CrossRef]

38. Sheldrick, G.M. SHELXT-Integrated space-group and crystal-structure determination. Acta Crystallogr. Sect. A 2015, 71, 3-8. [CrossRef]

39. Sheldrick, G.M. A short history of SHELX. Acta Crystallogr. A. 2008, 64, 112-122. [CrossRef]

40. Macrae, C.F.; Edgington, P.R.; McCabe, P.; Pidcock, E.; Shields, G.P.; Taylor, R.; Towler, M.; van de Streek, J. Mercury: Visualization and analysis of crystal structures. J. Appl. Crystallogr. 2006, 39, 453-457. [CrossRef]

41. Frisch, M.J.; Trucks, G.W.; Schlegel, H.B.; Scuseria, G.E.; Robb, M.A.; Cheeseman, J.R.; Scalmani, G.; Barone, V.; Petersson, G.A.; Nakatsuji, H.; et al. Gaussian 16, Revision B.01; Gaussian Inc.: Wallingford, CT, USA, 2016. 
42. Becke, A.D. Density Functional Thermochemistry III The Role of Exact Exchange. J. Chem. Phys. 1993, 98, 5648-5652. [CrossRef]

43. Lee, C.; Yang, W.; Parr, R.G. Development of the Colle-Salvetti correlation-energy formula into a functional of the electron density. Phys. Rev. B 1988, 37, 785-789. [CrossRef] [PubMed]

44. Hehre, W.J.; Ditchfield, R.; Pople, J.A. Self-Consistent Molecular Orbital Methods. XII. Further Extensions of Gaussian-Type Basis Sets for Use in Molecular Orbital Studies of Organic Molecules. J. Chem. Phys. 1972, 56, 2257-2261. [CrossRef]

45. Ditchfield, R.; Hehre, W.J.; Pople, J.A. Self-consistent molecular-orbital methods. IX. An extended gaussian-type basis for molecular-orbital studies of organic molecules. J. Chem. Phys. 1971, 54, 724. [CrossRef]

46. Petersson, G.A.; Bennett, A.; Tensfeldt, T.G.; Al-Laham, M.A.; Shirley, W.A.; Mantzaris, J. A complete basis set model chemistry. I. The total energies of closed-shell atoms and hydrides of the first-row elements. J. Chem. Phys. 1988. [CrossRef]

47. Norris, W.P.; Chafin, A.; Spear, R.J.; Read, R.W. Synthesis and thermal rearrangement of 5-chloro-4,6-dinitrobenzofuroxan. Heterocycles 1984, 22, 271-274. [CrossRef]

48. Smolobochkin, A.; Gazizov, A.; Sazykina, M.; Akylbekov, N.; Chugunova, E.; Sazykin, I.; Gildebrant, A.; Voronina, J.; Burilov, A.; Karchava, S.; et al. Synthesis of Novel 2-(Het)arylpyrrolidine Derivatives and Evaluation of Their Anticancer and Anti-Biofilm Activity. Molecules 2019, 24, 3086. [CrossRef] 